\title{
The Evolution Of Casualty Evacuation In The British Army In The 20th Century (Part 3) - 1945 To Present
}

\section{Bricknell}

\section{ABSTRACT}

This is the third in a series of papers describing the evolution of the British casualty evacuation chain during the 20 th century. This period was dominated by the threat of war between NATO and the Warsaw Pact in Central Europe. The Suez Crisis in 1956, the Falklands War in 1982, the Gulf War in 1991 and events in the Balkans during the 1990s demonstrated the requirement for a flexible system for medical support to the UK Armed Forces.

\section{Introduction}

This is the third in a series of papers that describe the development of the casualty evacuation chain in the British Army during the 20th Century. This paper covers the period 1945 to the end of the 20th Century. In the absence of a major war, there are no 'official histories' covering this period. This has made it more difficult to piece together the details of the changes in the evacuation chain and the organisation of field medical units than was the case for the previous 2 papers. In addition, there is substantially less published work on the subject of military medical organisation in Journal of the Royal Army Medical Corps due to the security limitations on publication during the Cold War. Military manuals, such as the Field
Lt Col MCM Bricknell

DM MMedSci

MRCGP MFOM

MFPHM DMCC

DRCOG RAMC

Chief Instructor,

Defence Medical

Services Training

Centre, Keogh Barracks,

Ash Vale, Aldershot,

Hants, GU12 5RQ.

Email:

mcm.bricknell@net.ntl.com

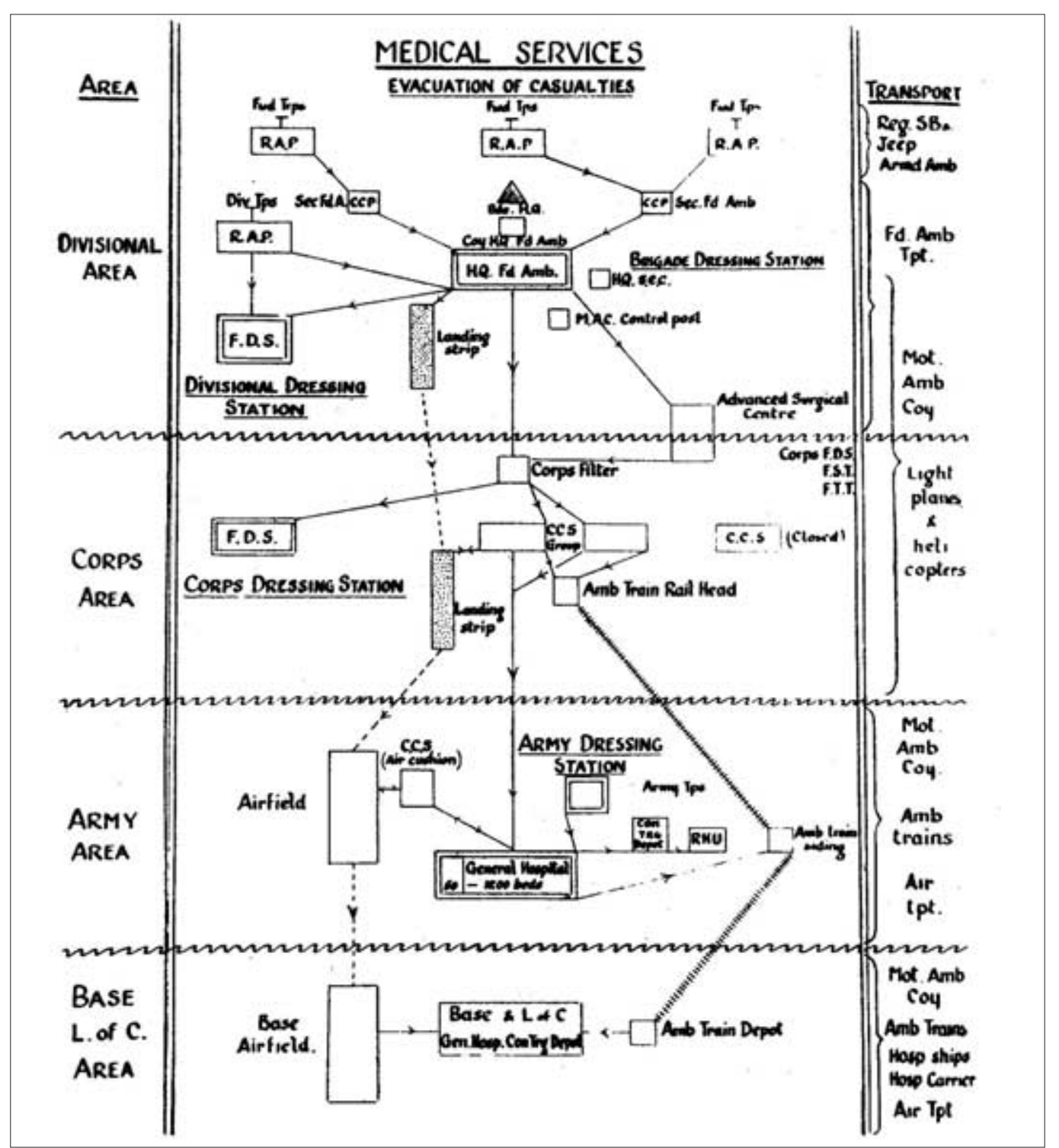

Fig 1. Post 1945 Casualty Evacuation Scheme. 
Surgery Pocket Book, were revised infrequently (the 1981 edition replaced the 1962 edition). Thus some of the information contained in this paper is based on personal recollections reported in a number of interviews conducted by the author. Finally, because this period is easily within living memory, readers are invited to correct any inaccuracies or misinterpretations contained in this paper through the correspondence section of the Journal so as to create an accessible record of this period in British military medical thought.

\section{The Korean War}

On 25 June 1950 Communist North Koreans invaded the anti-communist South. The decision was taken in July 1950 that Britain should contribute a land force to support the United Nations' effort. This was 27 Brigade from the Hong Kong garrison. It was necessary, even for a force of this size, to recall reservists - many of whom had already served in the Second World War. A second brigade was dispatched from UK, 29 Brigade, in 1951. These two Brigades came under command of the 1st British Commonwealth Division.

The casualty evacuation chain at the start of the Korean War (1) was unchanged from the Second World War. The Field Dressing Station (FDS) continued to exist as an independent organisation whose primary role was to maintain the fighting strength of the division by holding all minor sick, injured and mildly exhausted patients. The value of aircraft for the evacuation of casualties had been clearly established and the proximity of landing strips had become a factor to be considered in choosing the location of the Advanced Dressing Station (ADS) and the Casualty Clearing Station (CCS). As early as 1949, Dowse suggested if we can develop the Helicopter or some similar machine even this drawback (the constraint of siting medical units near airstrips) will go as these 'hoverflies' will be able to make use of landing spaces which are out of the question for ordinary types of light aircraft'. Thus the post-1945 casualty evacuation scheme added landing strips to the Hartgill scheme (2) (Figure 1).

EVACUATION: use of aircraft for casualty transport from Dressing Stations rearwards for $\mathbf{P} 1$ casualties

The clinical doctrine for surgical support also remained unchanged. The treatment of war wounds was regarded as a two-stage operation. The first, performed by the surgeon at the forward surgical centre, is concerned with the saving of life and limb and the preparation of wounds for the second stage by removal of debris and excision of non-viable tissue. The second stage - the closure of the wound - is carried out after evacuation where the patient can be held (3).

The medical plan for Korea was determined by geography (4). The countryside around the United Nations forces' defensive lines was characterised by extensive hills and mountain ranges. The road network was poorly developed with limited lateral communications. Close to the front line most casualty evacuation occurred by stretchers carried by stretcher bearers. Where vehicle evacuation was possible Universal (Bren gun) carriers were modified to take stretchers in order to give protection from small arms and direct fire.

\section{EVACUATION: front line evacuation} vehicles require protection

There were 3 field ambulances supporting the division : 25 Canadian Field Ambulance, 26 Field Ambulance (UK) and 60 Indian Parachute Field Ambulance. Each of these had a Field Surgical Team (FST) and Field Transfusion Team (FTT) attached, though the FSTs were more commonly employed with the Mobile Army Surgical Hospitals (MASH, vide infra). The British and Canadian field ambulances had elements of a Motor Ambulance Convoy attached to them (a total of 30 ambulances). The Canadians also provided a FDS of 200 beds to enable minor sick and wounded to be retained within the Divisional area. Surgical support to the Commonwealth Division was provided by a MASH about 10 miles down the Main Supply Route. This was a US Army medical unit that mirrored the function of a UK Casualty Clearing Station and provided forward surgery for battle casualties. The next stage in evacuation was by rail to the US 121 Evacuation Hospital near Seoul. Further evacuation was by Dakotas of the Royal Australian Air Force to Kure in Japan. Here casualties were admitted to the British Commonwealth Occupational Force Hospital, jointly staffed with British, Australian and Canadian surgeons (5).

\section{CLINICAL: use of FDS to retain minor sick within Commonwealth Division}

The Korean War saw the first co-ordinated use of helicopters for the evacuation of casualties. This evolved from a US Army helicopter force that was established to rescue shot down pilots. These helicopters proved so valuable in reducing the time from wounding to surgery that they became an asset dedicated by the US Army for casualty evacuation.

EVACUATION: use of helicopters by US Army 


\section{The Suez Operation}

In 1956 UK and France conducted a military airborne and amphibious landing onto the shores of Northern Egypt near Port Said, to prevent the Egyptian government taking control of the Suez canal. The military and political aspects of this operation are beyond the scope of this discussion. However, medically it was an important exercise (6). It was decided that casualties occurring during the invasion phase would be ferried from shore direct to ships of the landing force, thus many large spaces within the aircraft carriers and military transport ships were converted into hospital accommodation after the troops disembarked. Prior to embarkation all personnel earmarked for work in surgical teams (both Regular and Reserve) were posted to static military hospitals to get to know each other and to develop a team spirit. The need to be prepared to open the hospital facilities as quickly as possible led to the development of pre-sterilised and packed surgical sets of dressings, gloves, gowns etc, thus negating the requirement to sterilise this equipment as part of the process of setting up a hospital.

A number of medical units were involved in the Suez operation. The parachute assault onto El Gamil airfield by the 3rd Battalion Parachute Regiment Group was supported by 1 surgical team from 23 Parachute Field Ambulance. This team had had the benefit of working together in Cyprus before the parachute assault. They were surprised to find that some of the equipment that they were to use was wrapped in newspaper dated 1944! Urgent surgical operations were performed in a temporary operating theatre set up in a building on the airfield. Most casualties were evacuated by helicopter to ships at sea but there was also one lift of casualties by a French Dakota directly to Cyprus (7).

\section{EVACUATION: use of naval helicopters for evacuation of land force casualties to naval medical units.}

15 Field Ambulance supported the amphibious assault setting up an Advanced Surgical Centre with a FST attached to the ADS. No 2 CCS embarked upon the aircraft carrier HMS Theseus and provided surgical support for a number of Royal Marine Commandos injured in the landings on 6 November 1956. At dusk the unit disembarked and joined the ADS of 15 Field Ambulance and personnel from 23 Parachute Field Ambulance. Together they established a hospital ashore, initially in the Casino Palace Hotel and then in a school on Port Said sea front. The deployment of the equipment for 2 CCS had been done separately from its personnel leaving the Quartermaster with the significant problem of trying to identify the unit equipment from unmarked boxes and containers (7). 4 Field Dressing Station was mobilised with 3 FSTs. Initially this unit was to convert a troopship into a hospital carrier. After arrival in Port Said the task was changed and the unit established a hospital in the Port Said Ophthalmic Hospital (8).

\section{MOBILITY: requirement for CCS equipment to be tactically packed in order to facilitate establishment of unit.}

\section{The Cold War}

In the 1950s, the consequences of Nuclear and Chemical warfare were regarded as the principle medical challenges facing the Army Medical Services (6). It was anticipated that the casualty rate amongst soldiers would exceed even the experience of World War 1 in this type of warfare. Medical planning included 'mass casualties' whereby the demand for care would outstrip the capability available. The normal rules of triage would then be adjusted from prioritisation according to clinical need to prioritisation according to the patients' ability to benefit from limited intervention. Taking an arbitrary figure of 100 seriously injured casualties, it was judged that there would be insufficient surgeons to treat all patients requiring operation within 6 or even 96 hours of their admission to a hospital. It was estimated that it would take 8 days to complete the treatment of these casualties based on one surgical team and the workload achieved during World War 1. If the patients were appropriately prioritised and given sustaining treatment this 8-day backlog of surgical work was considered to be a reasonable planning figure.

\section{TRIAGE: creation of a 'mass casualty' triage system based on ability to benefit from intervention.}

This premise led to the personnel of static and field medical units being trained to form medical companies to which 3 or more surgical teams could be attached. Each medical company would contain 3 medical officers, 3 nursing officers, 37 nursing orderlies and some administrative personnel (9). The task was to admit and sustain 100 seriously ill patients for up to 8 days. These companies were designed to act as selfcontained units or to be grouped to form an evacuation or a general hospital. The company was made up of 3 sections each capable of running a 32 or 36 bed ward. The general hospitals and evacuation hospitals would be formed from a number of medical companies with an administrative headquarters plus the necessary medical, surgical and ancillary support. The FDS was to be 
formed from a headquarters plus two companies and the Field Ambulance formed from a company acting as the ADS and one company designed so each of its three sections could work as a casualty collection post.

In 1961, the Knott committee considered medical support for the land battle in the era of nuclear war (10). As a result the FDS was abolished and field ambulances reorganised to deploy a Main Dressing Station (MDS) and a number of collecting sections. Armoured ambulances were provided for units and field ambulances to protect casualties being evacuated from the front line.

\section{EVACUATION: creation of dedicated armoured ambulances.}

During the 1970s it was estimated that a conflict between the Warsaw Pact and NATO forces would generate 32,000 UK casualties

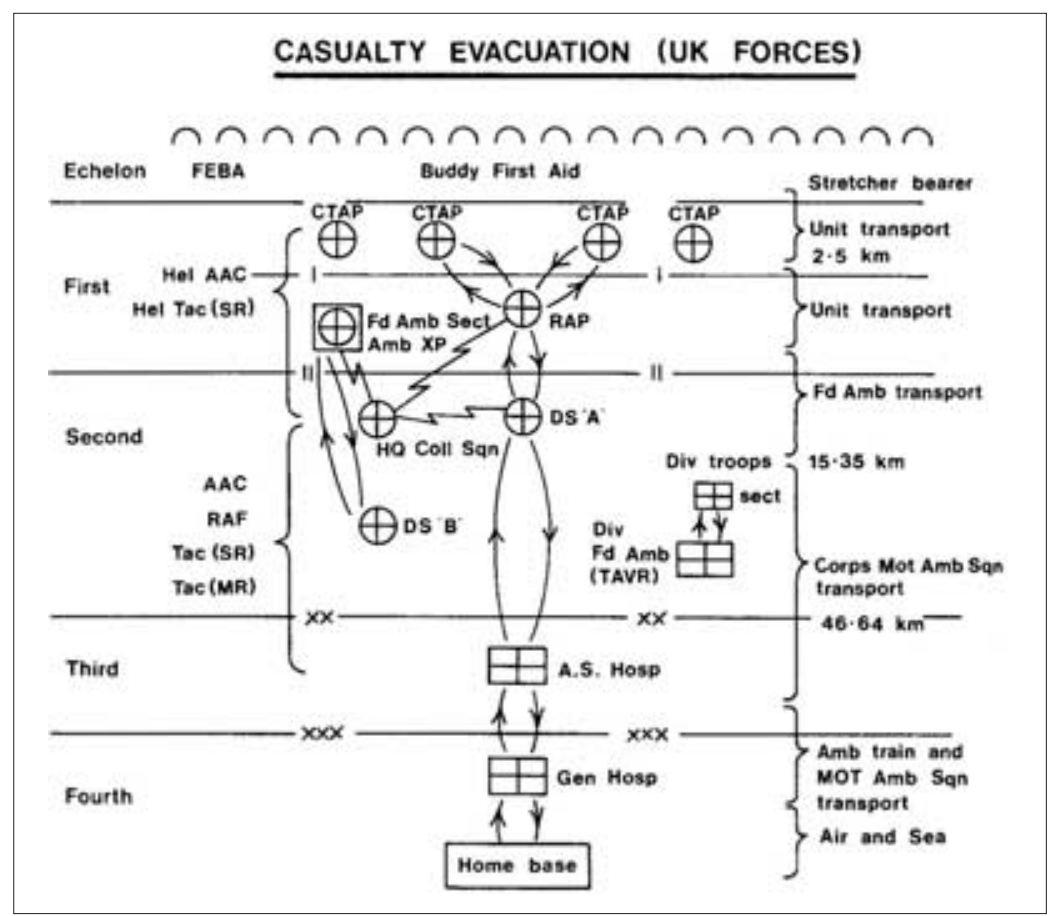

\begin{tabular}{|ll|}
\hline Key & \\
\hline FEBA & Forward Edge of Battle Area \\
\hline CTAP & Combat Team Aid Post \\
\hline RAP & Regimental Aid Post \\
\hline AAC & Army Air Corps \\
\hline SR & Short Range \\
\hline MR & Medium Range \\
\hline Amb XP & Ambulance exchange Post \\
\hline TAVR & Territorial Volunteer Reserve \\
\hline DS & Dressing Station \\
\hline RAF & Royal Air Force \\
\hline MR & Medium Range \\
\hline AS & Advanced Surgical \\
\hline Fd Amb Sect & Field Ambulance Section \\
\hline HQ Coll Sqn & Headquarters Collecting Squadron \\
\hline
\end{tabular}

Fig 2. Casualty Evacuation 1981. during an 8 day period. This was a more intense medical workload than the Second World War (11). The premise of 'hold and treat' of the $1950 \mathrm{~s}$ was revised into an evacuation chain that extended from the front line back across the English Channel to National Health Service hospitals. It was stated that all Priority 1 cases arriving at a field hospital were to receive their initial surgery in that unit within 8 hours and that some Priority 2 and 3 casualties were likely to deteriorate during evacuation. Thus all the Priority 1 and 2 casualties and $30 \%$ of the Priority 3 casualties would require surgical treatment on the continent, resulting in an estimated 866 casualties requiring resuscitation per day and 2,262 post-operative beds needed within the forward area (Corps level). The line of communication would require 11,500 beds through which casualties would pass on the way to the UK.

\section{SURGERY: creation of a Surgery WithIn Theatre (SWIT) and Surgery WithOut (SWOT) policy.}

The organisation of hospital support for a conflict in Europe was fundamentally reviewed (the Kirby report after the chairman, Major General NG Kirby then the Director of Army Surgery). The report observed that Field Hospitals, based on the World War 2 Casualty Clearing Stations, had few surgical teams (4 for Regular units and 2 for TA units) and no formal resuscitation department. The General Hospitals (1,200 beds) were similarly short of surgical potential as these were designed for holding and rehabilitation within an operational theatre and not as surgical hospitals. These units were too big for successful training in peace.

The casualty calculations showed that 50 surgical teams were required in the forward area. It was proposed that the forward hospitals (field hospitals) should be reorganised into hospitals of 8 surgical teams and 400 beds. The hospitals on the line of communication were to be re-organised to provide three General Hospitals of 800 beds with 3 surgical teams in the forward communication zone and a number of specialist and evacuation hospitals further down the evacuation chain. Most of these changes applied to the Territorial Army, but the Regular Army field hospitals were changed from 200 bed units to 400 bed units and called 'Advanced Surgical Hospitals'. The 800 (6 surgical teams) bed hospitals remained as 'General Hospitals' and a new type of hospital of 400 (4 surgical teams) beds was created to serve the purpose of evacuation across the Channel. These were called 'Port Hospitals' (later designated 'Evacuation Hospitals'). The generic scheme of evacuation is shown at Figure 2 (12).

Military hospitals earmarked for the British Army of the Rhine had a very clear 
mission with the precise operational location already earmarked. This rejuvenated clinical military medicine and led to the publication of a revised Field Surgery Pocket book in 1981 (12) and the production of Casualty Treatment Regimes (CTRs) in 1986 (13). The former publication provided the modern, theoretical basis for military surgery and the latter, an easily accessible set of guidelines for the standardised treatment of military casualties.

\section{CLINICAL: creation of standardised clinical protocols (CTRs) for use at all stages in casualty evacuation chain.}

Most operational locations were in buildings, limiting the need for investment in effective field hospital shelter systems. The internal organisation of a field hospital was described in training materiel taught at the RAMC Training Group (14). Military hospitals had two functions; the provision of treatment that would permit a casualty to return to duty immediately or a short period (72 hours) and the provision of the minimum treatment necessary to enable the casualty to survive evacuation to the next line of hospitals. A hospital was organised into the following departments to meet these functions: reception, resuscitation/pre-op, surgical centre, wards, evacuation, minor treatment, X-ray, pathology laboratory and administration. The resuscitation department was organised into two types of team, a crash team (a medical officer, a nursing officer and a medical assistant acting as a transfusion orderly) to initiate treatment and a maintenance team (a nursing officer, an enrolled nurse and 2 medical assistants) to look after up to 10 casualties after treatment had been started. The surgical centre was equipped with up to 4 operating tables and 8 surgical teams to allow round the clock operating by 4 teams simultaneously. Hospital documentation would only have been initiated for surgical cases, thereby avoiding this administrative task for the low priority casualties (for whom the basic field medical record was used). The wards were designed for post-operative cases only but the number of casualties precluded the establishment of separate intensive care facilities. It was anticipated that casualties requiring evacuation would be held in the evacuation department and not admitted to hospital wards. The X-ray departments and laboratory were equipped to provide simple investigations that were essential for decisions on initial treatment only.

CLINICAL: AMS field medical system designed to deliver quantity at expense of quality.
Out-of-area Capability

The withdrawal of UK strategic forces 'East of Suez' in the 1960s saw the creation of a military strategic reserve capable of being flown to a trouble spot anywhere in the world. It was recognised that the style of medical organisation required to support this force was substantially different from that needed in Central Europe. UK airborne forces were the lead element of the plan for a National military response outside of Central Europe. This was supported by 23 Parachute Field Ambulance. The fragility of the evacuation chain in airborne operations is unchanged from World War II so this unit retained its integral surgical capability that had been so useful for the Suez operation (15).

The standard task of surgery and resuscitation of Priority 1 casualties was augmented by the need to hold minor sick and injured in country to limit the 'overevacuation' of minor sick. Such a unit would require a combination of the capabilities of a field ambulance and a CCS (16). The only 'out-of-area' (ie. not dedicated to a military conflict in Europe) hospital capability maintained from the 1960s to the early 1990s was 2 Field Hospital based in Aldershot. This unit changed designation from a CCS to a field hospital in August 1969. This was maintained as a 'cadrised' unit of 3 officers and 38 soldiers but expandable up to 48 officers and 141 soldiers to achieve a 200 bed capability.

The unit deployed on September 1970 to Jordan to assist with an international humanitarian relief effort after a period of civil war (17). Overall, it was a very successful use of British military medical services. However the deployment of a 50 bed element of a field hospital identified a number of familiar issues. The equipment needed palletisation, the resuscitation department needed augmentation with a nursing team and the movement of the unit in Jordan was problematic due to the absence of dedicated unit vehicles.

\section{MOBILITY: requirement for field hospital equipment to be tactically packed in order to facilitate establishment of unit.}

\section{Falklands War 1982}

The bulk of the UK Armed Forces were focused towards the threat of a conflict in Europe. When Argentine forces invaded the Falkland Islands in the South Atlantic on 2 April 1982 there was no formal planned evacuation chain to provide medical support to such a conflict. The first elements of the UK Task Force left from Portsmouth on 5 April. The landing operation started on 21 May and the Argentine forces surrendered on 14 June. The main medical challenge was 


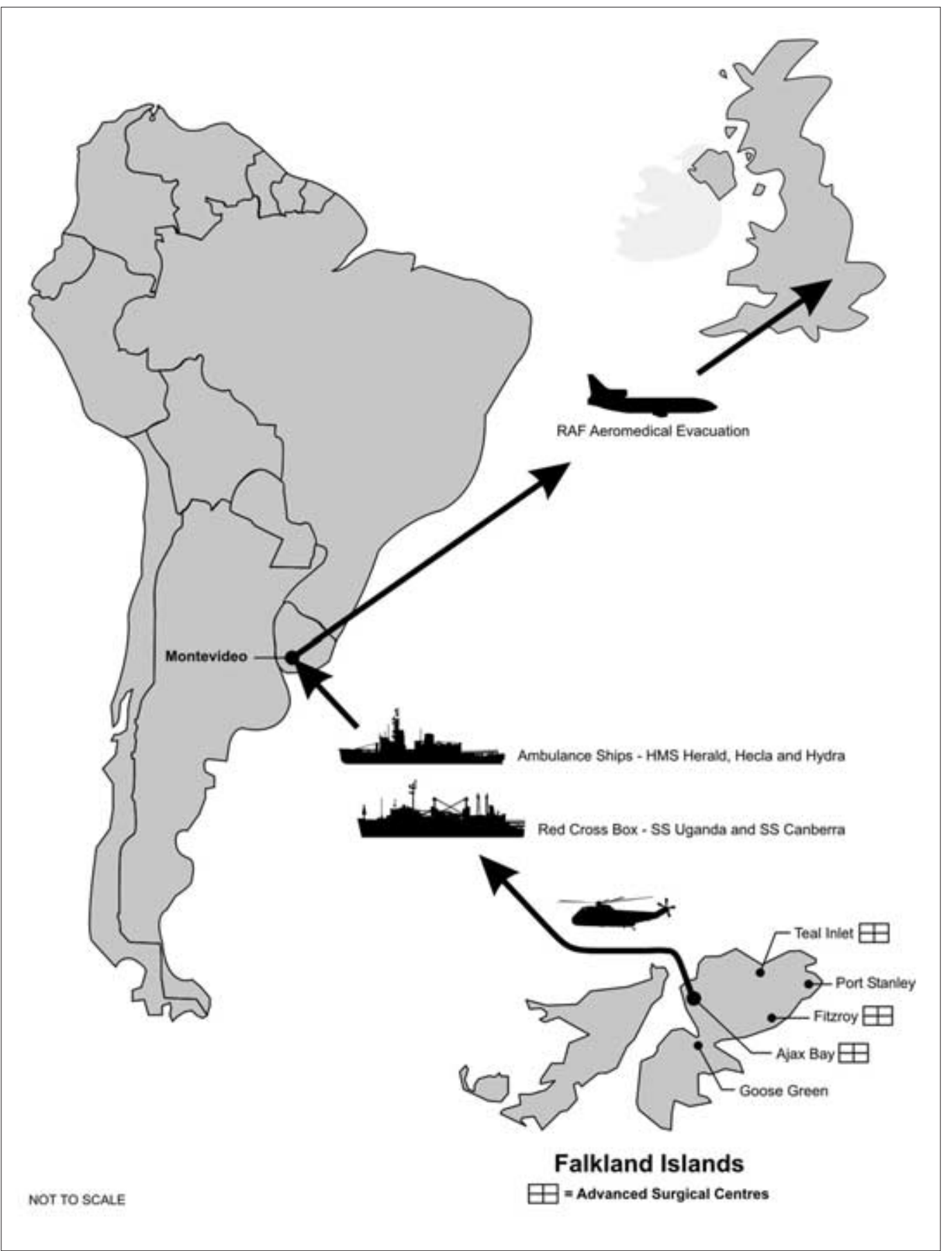

Fig 3. Scheme of evacuation for the Falklands War.

the organisation of an evacuation chain over a distance of almost 8000 miles (18). This would involve elements from the Royal Naval, Army, and Royal Air Force medical services. Casualties were hand carried from the front line to the Regimental Aid Posts. They were picked up by helicopter and taken to the nearest Advanced Surgical Centre. A combined unit formed from the Parachute Clearing Troop and the Commando Medical Squadron initially supported the bridgehead at San Carlos. This unit, based at Ajax Bay, provided forward surgery prior to evacuation of casualties by helicopter to SS Uganda. As the land operation moved East, Advanced Surgical Centres were established at Fitzroy (including 2 surgical teams) and Teal inlet. Each Field Surgical Team consisted of a surgeon, anaesthetist, resuscitation officer, 4 operating theatre technicians and a clerk. They were supported by a holding section of a medical officer and 18 nurses and medical assistants to provide nursing and postoperative care (19). These Advanced Surgical Centres provided basic surgical care for those patients who would have died if their operation had been delayed until the arrival of the casualty at a hospital ship. SS Uganda, a cruise ship, was requisitioned was converted into a dedicated hospital ship and was supported by three 'ambulance ships' Hecla, Hydra and Herald. These small ships were used to ferry casualties from the Uganda to Montevideo, Uruguay for transport by air back to UK. This is shown graphically in Figure 3. 


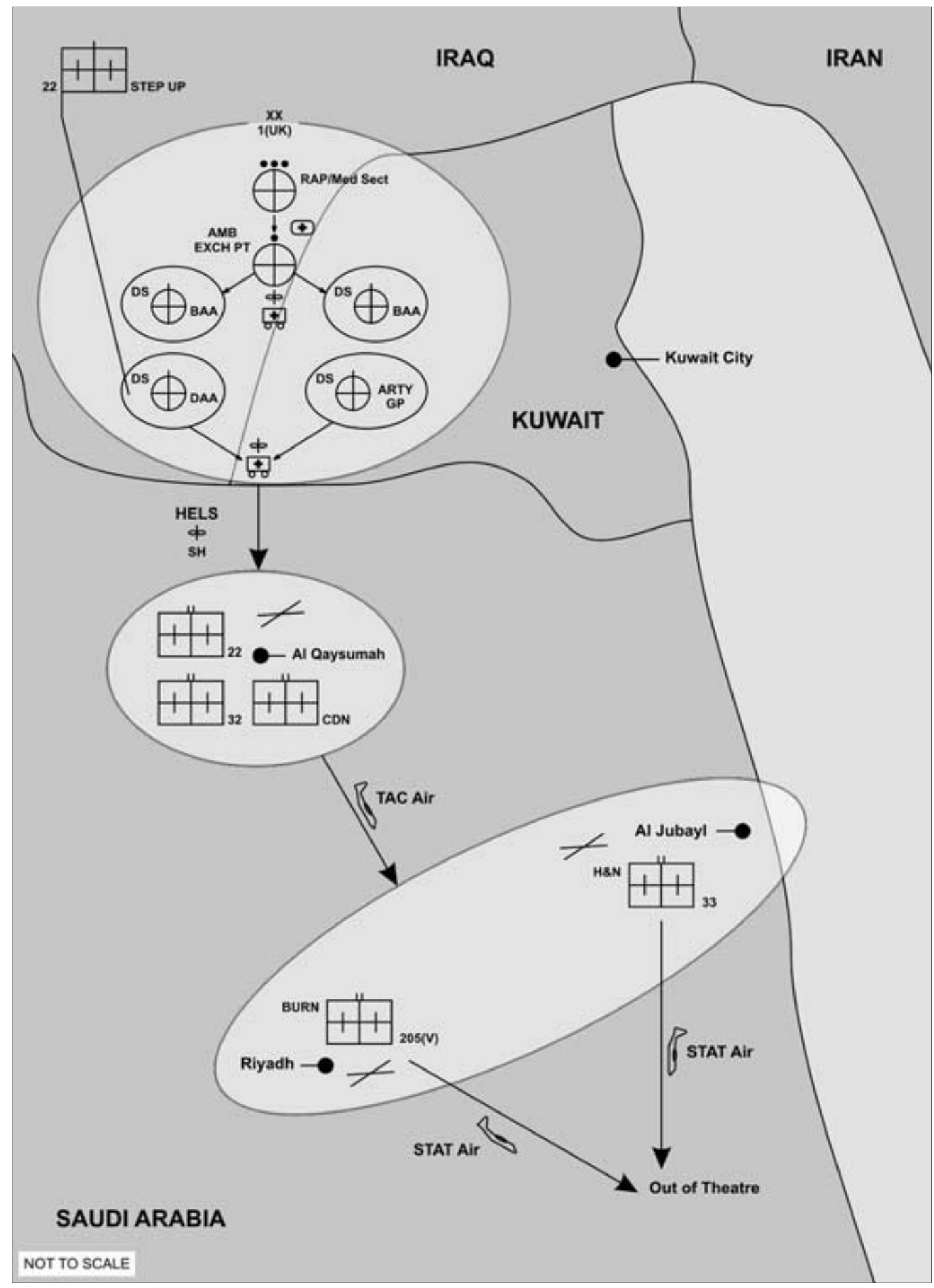

\begin{tabular}{|c|c|c|c|c|c|}
\hline \multicolumn{4}{|l|}{ Key } & \multirow{4}{*}{$\begin{array}{l}\phi \\
+0 \\
\oplus\end{array}$} & \multirow{3}{*}{$\begin{array}{l}\text { Helicopter } \\
\text { Ambulance }\end{array}$} \\
\hline RAP & Regimental Aid Post & Med Sect & Medical Section & & \\
\hline DS & Dressing Station & BAA & Brigade Administrative Area & & \\
\hline Arty Gp & Artillery Group & HELS & Helicopters & & Field hospital \\
\hline CDN & Canadian & TAC & Tactical & \multirow{2}{*}{ 世1 } & \multirow{2}{*}{$\begin{array}{l}\text { Medical facility } \\
\text { (squadron size) }\end{array}$} \\
\hline STAT & Strategic & H\&N & Head and Neck & & \\
\hline
\end{tabular}

Fig 4. Casualty Evacuation Chain UK Gulf 1990.

\section{SURGERY: extended evacuation chain may require surgery forward of hospital facilities.}

\section{Gulf War}

Although written in 1979, the proposals contained in the Kirby Report took some time to implement. The designation of units was changed and the plan for the purchase and re-allocation of equipment was still underway in 1987 (20). In addition, a scenario involving a slow transition to war and a less intense conflict led to the recognition that hospitals should also be able to manage patients with disease and 
non-battle injuries. Specialist support for these conditions was also included within the manpower of the military hospital.

The political and military background to the GulfWar (1990-1991) for the liberation of Kuwait is well documented. This was a huge expeditionary deployment of UK forces from bases in UK and Germany to Saudi Arabia, a very different response to that planned to meet the threat from Eastern Europe. The war was a classic example of armoured warfare fought over open spaces with few constraints to movement. There was a continual threat of the use of nuclear, bacteriological and chemical weapons, though fortunately this never materialised. UK medical planning had moved from the fixed plans of the European front of the Cold War to supporting forces moving large distances operating a huge distance from the home base.

The UK plan for medical support is described in Gulf Logistics (21). Over a period of 3 months a complete medical service of 4 hospitals, a hospital ship, 5 field ambulances and numerous smaller units were deployed to the region. Much of the equipment for the medical services had been orientated towards the short, intense war senario of the Cold War with the consequent large casualty predictions that limited medical care to evacuation and transport back to UK. Much of the equipment issued from depots had been designed in the 1940 s with little revision to accommodate the needs of modern medicine and indeed the casualties from disease that were not a significant element of the Cold War medical plan. The experience of the field hospital supporting the land forces exemplified the problems of attempting to apply medical doctrine, designed for General War in Germany, to a totally different operation.

The huge distances and mobility of the anticipated land operations dictated the layout of the medical plan. The overall plan is shown in Figure 4.

Casualties were evacuated to Regimental Aid Posts and then to dressing stations according to the template used since World War 1.The field ambulance dressing stations were reinforced with field surgical teams to provide expert resuscitation to the most seriously injured casualties. It is considered that this arrangement saved at least 4 lives that might otherwise have been lost (22). They were then moved by ambulance or helicopter to the 'Forward Surgical Complex' formed by two field hospitals (22 and 32), a field ambulance, an aeromedical squadron, an ambulance transport squadron, a medical stores unit and a field psychiatric team. 32 Field Hospital was established in its forward position on 20 January 1991. It comprised a reception/triage area, an eight bay resuscitation department, a treatment area, an eight table operating theatre and 200 beds in 4 wards. This was supported by a pathology department and a X-ray department (23). A lesson of this experience was that the forward group of field hospitals needed to be re-configured in smaller, redeployable units.

\section{SURGERY: extended evacuation chain may require surgical resuscitation forward of hospital facilities.}

Casualty evacuation in the forward areas was almost universally by helicopter from the casualty collection post (RAP or medical section) to the field hospital. They were then moved by C130 to the 600 bed General Hospitals at Jubail (33) or Riyadh (205). After further treatment they were flown back to UK in VC10s or TriStars (24).

\section{The 'out-of-area' Story Continues}

The Falklands War re-emphasised the need for contingency forces for 'out-of-area' operations and an Airborne Brigade was reestablished. 23 Parachute Field Ambulance was reformed (15). Composite units with surgical support based on 23 Parachute Field Ambulance were used in Rwanda in 1994 (25), the Congo in 1997, Kosovo in 2000 and Sierra Leone in 2001. 2 Field Hospital was re-designated 22 Field Hospital in 1986. This unit was closely aligned with the medical plan for Brigade level 'out-of-area' operations (26). 22 Field Hospital experi-mented with smaller levels of hospital support for 'out-of-area' operations and devised the 50 bedded Medical Support Troop (MST). MSTs were extensively used in the 1990s in Bosnia (vide infra). In addition, in February 1995, a MST was deployed to Lobitio Port in Angola as part of a composite medical force including elements from 4 Field Ambulance and a RAF aeromedical evacuation team to provide medical support to the United Nations Angolan Verification Mission. The unit was set up in a warehouse in the port and personnel were accommodated in a Royal Fleet Auxillary landing ship moored alongside. This concept was used by 34 Field Hospital in providing hospital support to British forces in Sierra Leone in 2001 when a hospital facility was built on hardstanding in Freetown port and personnel were accommodated aboard a landing ship moored alongside. 
MODULARITY: field hospitals required to deploy capabilities ranging from 25 to 200 beds.

\section{Peace Support Operations In The Balkans}

The Army Medical Services were initially involved in the Balkans through the provision of a field ambulance to support a UN peacekeeping force in Croatia in 1992. The civil war expanded to Bosnia and the UK provided an armoured infantry battalion with supporting logistics to assist the $\mathrm{UN}$ in the movement of food and other humanitarian relief. A composite medical unit was formed from 1 Armoured Field Ambulance and a Medical Support Team (MST) from 22 Field Hospital (27). The MST was established in prefabricated huts in Vitez to provide surgical cover to the UK force. A second MST deployed in July 1995 to Divulje Barracks in Split. Here they set up a resuscitation department, an operating theatre, a 20 bed ward supported by laboratory and X-ray services. This unit returned to UK on 1 October after the French and German military medical services had established a field hospital in the area (28). The Bosnian situation changed in late 1995 with the signing of the Dayton peace accord leading to the deployment of a large number of troops in a NATO led operation to implement the agreement. The UK deployed a number of medical units including a MST from 22 Field Hospital to Gornji Vakuf (GV) and the remainder of the unit (as a 50 bed hospital) to Tomislavgrad (TSG). The MST set up in pre-existing portacabins whilst the hospital at TSG was established in a disused warehouse. This hospital consisted of a reception area, treatment area, resuscitation, two wards of 25 beds, an intensive therapy area, a pathology laboratory, X-ray, an operating theatre and a medical stores department (29). A small hospital facility was also established in Sipovo under command of 16 Armoured Field Ambulance. A number of visits to other nations military field hospitals were undertaken during this deployment. These observed the extensive use of expandable, containerised medical shelters that seemed to offer some advantages compared to the tent-based systems currently in use in the British Army. In June 1996 the hospital in TSG was taken over by 23 Parachute Field Ambulance and designated as a hospital squadron and 22 Field Hospital returned to UK. The facility in TSG was closed in October 1996 and the focus for hospital support shifted to Sipovo.

A hospital facility continues in Sipovo. This was augmented with a containerised surgical unit (made by GIAT industries) in 1997. The facility was redesigned and improvement work undertaken. In 1999 the hospital became a multi-national facility with staff being provided from UK, the Netherlands, Canada, Czechoslovakia and Iceland. This facility has provided a service more aligned to that provided by a District General Hospital in UK than a 'Cold War' field hospital. There is a hospital standard operating theatre in a hard-walled, fixed facility supported by two fully specified Level 3 critical care beds. The X-ray department has a digital system linked to a reference department in Europe and the laboratory provides a full range of emergency investigations supporting both surgical and medical patients.

The situation in Kosovo deteriorated in 1998. This was followed by a series of powerful diplomatic and military initiatives leading to the deployment of land forces in 1999. The UK initially deployed a composite medical unit based on 2 Armoured Field Ambulance that included a surgical resuscitation capability from 23 Parachute Field Ambulance. In June 199922 Field Hospital was deployed to the region to support the insertion of a peace implementation force from Macedonia to Kosovo. The unit set up a 50 bed field hospital in a disused prison in Lipljan. This facility was redeployed to a bespoke facility built in a British military sector in Pristina in November 1999. This hospital facility remained in use until the middle of 2001 when the British and US Army agreed to work together from a medical facility set up in the US base at Camp Bondsteel.

The Balkans experience demonstrated that medical planning for non-warfighting scenarios should not be based on casualty estimates that derive the surgical requirement from high intensity operations. Medical support evolved to meet the estimates for Disease and Non-Battle Injury (DNBI) casualties with a reserve designed to respond to a major incident based on a transport accident (e.g. coach or helicopter crash). The configuration of medical assets developed into a 'hub and spoke' framework to provide area medical support as compared to the linear evacuation chain designed for warfighting. This rendered the Dressing Stations of field ambulances redundant as casualties were evacuated from point of injury direct to field hospitals. The sick were 'bedded down' at the RAP or field hospital.

EVACUATION: removal of Dressing

Station from the casualty evacuation chain at low casualty rates.

\section{Front Line First Followed By The Strategic Defence Review}

The experience of the 1990s showed that the 8 day, high-intensity war with few medical casualties was not the most likely threat. In 
reality, any conflict is likely to have a period of 'transition-to-war' that will generate disease and non-battle casualties. The Ministry of Defence conducted several reviews of expenditure during the 1990s to achieve savings from the reduced threat of a war in Europe as a result of the break-up of the Soviet Union. The first review (Options for Change) proposed 4 field hospitals, 22 Field Hospital (as previously described) and 3 based on existing military hospitals in Aldershot, Catterick and Rinteln (Germany). Subsequent reviews, Front Line First and the Defence Costs Study, closed all 'stand alone' Army military hospitals (30). Two additional Regular deployable field hospitals were created based on the 200 bed cadrisation model used by 22 Field Hospital. These were designated 33 and 34 Field Hospital. A further 11 field hospitals (of 200 bed capacity) were to be provided by the Territorial Army (31).

\section{The British Army Field Medical Services Into The 21st Century}

The 1990s could be considered to have heralded a renaissance of military medical thinking. A key driver has been a new policy that medical support and patient care should be as closely equivalent to peacetime UK standards as is compatible with battlefield conditions. This is fundamentally different from the Cold War doctrine that assumed medical care would be under 'mass casualty' conditions and therefore it was not possible to apply peacetime standards.

\section{CLINICAL: quality of military medical care aligned to peacetime national standards.}

Medical doctrine was written for both Joint operations (32) and Army operations (33). The Field Ambulances were amalgamated and ambulance transport was brought under medical control through the creation of the Medical Regiments (34). The Close Support Medical Regiment provides tighter alignment of command and control of the Dressing Stations providing close support to the front line brigades and brings casualty evacuation from Dressing Stations to the Field Hospitals directly under command of a General Support Medical Regiment. Field surgical teams have been provided for the Dressing Stations to enable 'damage control surgery' to be provided for the most seriously injured. Medical cover and movement of casualties behind the division are under the control of a second General Support Medical Regiment.

Hospital level medical support has been studied under the auspices of the 3rd Line Medical Study (35). This paper defined the function of deployed hospitals as follows: the saving of life, minimisation of residual disability and preparation of casualties for evacuation; diagnosis and treatment of those suffering disease; provision of routine diagnostic support to Primary Health Care units (e.g. X-ray and laboratory investigation); provision of a specialist advisory and reference service including outpatients to Primary Health Care. The expectations of mass casualties in a European War had led to the removal of the 'intensive care' capability from the field hospitals on the assumption that casualties needing this level of care would have been classed as 'expectant'. They would have received compassionate care only. This is only a tenable assumption in 'mass casualty incidents' and thus intensive care is required within field hospitals (36). Hospitals supporting war fighting may need to be divided into 2 groups. The Forward Group of hospitals need to be modular, easily deployable and re-deployable with sufficient capacity to provide primary surgery to all casualties and equipped to deliver peacetime standards of care when casualty flows are low. The Rear Group of hospitals need to be deployable (but may not need to re-deploy within a theatre of operations). These may be larger and equipped for peacetime standards of care.

\section{Summary}

The years after World War II were dominated by the Cold War. The range of medical units developed as a result of the Hartgill Committee of the Second World War was gradually reduced. The scale of the medical task faced during the Cold War led to the concept of forward surgery provided by mobile units being replaced by a concept of static field hospitals undertaking selective surgery with the main medical effort being focussed on the movement of large numbers of casualties through the evacuation chain to UK. The Field Surgical Team, Field Dressing Station and Casualty Clearing Station were all removed from the order of battle. Whilst it was hoped that helicopters and aircraft might be available for casualty evacuation no facility was made for dedicated resources. Fortunately this plan was never tested and all actual operations were conducted 'out-ofarea'. Each of these operations exposed deficiencies in the organisation and equipment of the Army Medical Services.

Field hospitals were organised to provide austere surgical care for military trauma from fixed locations. The medical units designed to support mobile warfare (the Field Surgical Unit, Field Transfusion Unit and Casualty Clearing Station) in World War II had been removed, though 23 Parachute Field Ambulance and 22 Field Hospital remained as guardians of these intellectual concepts. Intensive care, sustained post-operative nursing and the management of medical cases had not been provided because these were not practical in an intensive short-war 
scenario. The Gulf War brought these deficiencies into sharp focus: the resulting medical plan having more in common with World War 2 (Figure 1) than the Cold War (Figure 2).

The overall capacity of the military medical system is determined by the estimate of casualties arising from a particular military deployment. The 'certainties' of the Cold War were replaced by a changed strategic situation in the 1990s. This made it more difficult to define the specific threat against which the UK Armed Forces might be designed. Thus forces were to be based on a capability for deployment outside Europe for a range of military operations. This fundamentally changed the planning assumptions for the medical services and led to the very significant re-organisation of field ambulances into Medical Regiments.

\section{Acknowledgments}

This project was supported by a short-term research fellowship in the history of medicine from the Wellcome Trust.

The auther wishes to thank Capt (Rtd) P Starling and the staff of the AMS museum for their support to this project.

\section{References}

1. Cameron RD. The British Army Divisional Medical Organisation. If $R$ Army Med Corps 1951;106:236-242.

2. Dowse JCA. A concept of some of the principles involved in the tactical employment of forward medical units. F R Army Med Corps 1949;97:168186.

3. A Field Surgery Pocket Book. The War Office. HMSO 1950.

4. Anderton G. The Birth of the British Commonwealth Division, Korea. 7 R Army Med Corps 1953;108:43-54.

5. Watts JC. Surgeon at War. Digit Books London 1960.

6. Drummond A. Military Medical Problems in Britain Today. Milit Med 1957;3:163-173.

7. Interview with Major General (Retd) NG Kirby 19 Feb 02.

8. Unit records. The Army Medical Services Magazine. 1957;9:16-17.

9. The Management of Mass Casualty Situations in War. AMD 7 War Office12255 Jan 1958.

10. Cited in Lillywhite LP. Future Medical Support in the Armoured Division. Staff College paper 1982.

11. D/AMD/52/1/2/1 (AMD1a) Report of the Army Medical Directorate Working Party on Hospital Support for BFG in War ('The Kirby Report') 8 Nov 1979.
12. Field Surgery Pocket Book. Ed Kirby NG. HMSO London 1981.

13. Casualty Treatment Regimes First Edition. HMSO 1986.

14. Medical Support in the Field. The Army Medical Services in War. RAMC Training Group.1992.

15. Lillywhite LP. Medical Support of Airborne Operations. f R Army Med Corps 1988;134:59-64.

16. Shaw AJ. The medical support of a small airlanded force. $\mathcal{F}$ Royal Army Med Corps 1969;115:19-22.

17. Goodall TM. Operation Shoveller. The deployment and task of 2 Field Hospital RAMC. $\mathcal{F}$ R Army Med Corps 1971;117:59-66.

18. A short but distant war - the Falkands Campaign. f R Soc Med 1983;76:972-982.

19. Jackson DS, Batty CG, Ryan JM and McGregor WSP. The Falklands War: Army Field Surgical Experience. Ann R Coll Surg 1983;65:281-285.

20. D/SG Ops/466/2/38/Med Ops \& Plans 31 Jan 1987.

21. Lillywhite LP and Leitch RA. Medical Support in Gulf Logistics. Blackadder's War. Ed White MS Brassey's Exeter 1995.

22. Braithwaite MG. Field Ambulance deployment. In Gulf Symposium British Military Hospital Hannover 30th Nov 91

23. Spalding TJW, Stewart MPM, Tulloch DN and Stephens KM. Penetrating missile injuries in the Gulf War 1991. Br F Surg 1991;78:1102-1104.

24. Martin TE. Al Jubail - an aeromedical staging facility during the Gulf conflict: discussion paper. f R Soc Med 1992;85:32-36.

25. Hawley A. Rwanda 1994: A Study of Medical Support in Military Humanitarian Operations. $\mathcal{F} R$ Army Med Corps 1997;143:75-82.

26. Interview Major General (Retd) AJ Shaw 5 Feb 2002.

27. The Army Medical Services Magazine. 1993;47:104105 .

28. The Army Medical Services Magazine. 1996;52:7-8.

29. The Army Medical Services Magazine. 1996;52:122124.

30. House of Commons Defence Committee. Fifth report. Defence Costs Study Follow-up: Defence Medical Services. HMSO London 5 Apr 1995.

31. House of Commons Defence Committee Third report. Defence Medical Services. HMSO London 19 Feb 1997.

32. Joint Warfare Publication 4-03 Joint Medical Doctrine.

33. Army Doctrine Pamphlet Part 3 Logistic Medical Supplement April 2000.

34. Macmillan AHMcG. Farewell field ambulance, hail medical regiment. $f R$ Army Med Corps 2000;146:62-63.

35. HQ Land 3rd Line Medical Study. Phase 2. Medical Requirements. Land/Med/3471 dated 18 Mar 00.

36. Craig RP. Preparations made and lessons learned by the UK Defence Medical Services during Op Granby. 7 US Army Med Dep 1992; Mar-Apr:2630 